Summer 2011

\title{
Introduction: Transnational Corporations Revisited
}

Gralf-Peter Calliess

Law Department, University of Bremen, Germany, calliess@web.de

Follow this and additional works at: https://www.repository.law.indiana.edu/ijgls

Part of the Business Organizations Law Commons, International Law Commons, and the Transnational Law Commons

\section{Recommended Citation}

Calliess, Gralf-Peter (2011) "Introduction: Transnational Corporations Revisited," Indiana Journal of Global Legal Studies: Vol. 18 : Iss. 2 , Article 1.

Available at: https://www.repository.law.indiana.edu/ijgls/vol18/iss2/1

This Symposium is brought to you for free and open access by the Law School Journals at Digital Repository @ Maurer Law. It has been accepted for inclusion in Indiana Journal of Global Legal Studies by an authorized editor of Digital Repository @ Maurer Law. For more information, please contact rvaughan@indiana.edu.

\section{$\Psi$}

JEROME HALL LAW LIBRARY

INDIANA UNIVERSITY

Maurer School of Law
Blooming ton 


\title{
Introduction
}

\section{Transnational Corporations Revisited}

\author{
GRAlf-Peter CALliess*
}

Transnational corporations are not a new phenomenon. ${ }^{1}$ The extension of economic activities across national borders since the end of World War II caused transnational corporations to spread to an extent capable of significantly affecting societal matters. This development did not go unnoticed in academic discussions. Transnational corporations have been of major scientific interest since the 1960s. Stephen Hymer, an early pioneer in this area, analyzed the organizational mechanisms of multinational corporations. ${ }^{2}$ The exploding number and size of private enterprises on a global scale mesmerized many authors, who called such enterprises "cosmocorps" 3 and "a challenge to the nation-

* Dr. iur. (J.S.D.), 1998, Universität Göttingen. Professor for Private Law, International and Comparative Commercial Law, Law Department, University of Bremen, Germany. Please send mail to calliess@web.de. Many thanks to Peer Zumbansen and Fred Aman for chairing the sessions. Special thanks to Jens Mertens for his help in conceptualizing the symposium and for his excellent research assistance in drafting this introduction. Much appreciation to the local organization committee of the conference. Funding by the German Ministry of Justice (BMJ) and CRC 597 is gratefully acknowledged.

1. This contribution serves as an introduction to the articles on transnational corporations collected in this issue. The articles were first presented at a symposium in the context of the biannual conference of the German Law \& Society Association (Vereinigung für Recht und Gesellschaft e.V.) on "Transnationalism in Law, the State, and Society." This conference was organized together with the Collaborative Research Center (CRC) 597 "Transformations of the State" at the University of Bremen from March 3-5, 2010. The Collaborative Research Center 597 "Transformations of the State," U. BREMEN, www.staat.uni-bremen.de (last visited Jan. 21, 2011).

2. See generally StEPHEN HERBERT HYMER, THE INTERNATIONAL OPERATIONS OF NATIONAL FIRMS: A STUDY OF DiRECT FOREIGN INVESTMENT (1976) (arguing that direct foreign investments help firms in their international operations by aiding in controlling production, curtailing competition, or creating capital from monopolizing advantages like skilled labor or inexpensive raw materials).

3. E.g., George W. Ball, Cosmocorp: The Importance of Being Stateless, CoLuM. J. WORLD BUS. Nov.-Dec. 1967, at 25, 25.

Indiana Journal of Global Legal Studies Vol. 18 \#2 (Summer 2011)

(C) Indiana University Maurer School of Law 
state." 4 In the early 1970s, authors like Raymond Vernon in his book, Sovereignty at Bay: The Multinational Spread of U.S. Enterprises, ${ }^{5}$ and Samuel P. Huntington in his seminal article, "Transnational Organizations in World Politics," 6 were at the forefront of questioning the fundamental relationship between nation-states and transnational organizations. By the early 1990s, the importance of transnational corporations vis-à-vis nation-states as influential actors on the international level had already been clearly stated. ${ }^{7}$

So why revisit a subject already discussed in the 1970s today? Because the world has seen enormous change over the last few decades, which has affected the role of transnational corporations in what is now perceived as a globalized society. While Huntington claimed in the early 1970s that transnationalism-as opposed to European colonialism-is the "American mode of expansion," 8 and many economists thought that transnational corporations were in fact national corporations with international business activities, ${ }^{9}$ others predicted that in the future there would be no national products, technologies, corporations, or industries, but only global economics. ${ }^{10}$ In 1990, for instance, Kenichi Ohmae stated: "In today's 'Interlinked Economy,' global corporations have effectively become nationalityless." 11 In fact, in 2011 we witness not only an era with more, bigger, and increasingly influential transnational corporations than any time before (see section II), but also

4. Daniel Jay Baum, The Global Corporation: An American Challenge to the NationState?, 55 IowA L. REV. 410, 410 (1969).

5. RAYmond Vernon, Sovereignty at Bay: The Multinational Spread of U.S. ENTERPRISES (1971). Vernon describes this piece as portraying "an incipient clash between two strong systems-a system of nation-states responding to the imperatives of its citizens, and a system of enterprises reacting to the increasing opportunities induced by technological change." Raymond Vernon, This Week's Citation Classic, CURRENT CONTENTS: SOC. \& BEHAV. SCI., no. 3, Jan. 21, 1985 (book review of SovEREIGNTY AT BAY 1971). Vernon contends that this class "could prove destructive if an international response to the clash [is] not developed." Id.

6. Samuel P. Huntington, Transnational Organizations in World Politics, 25 WORLD POL. 333 (1973) (analyzing "the sources, nature, and dynamics" of the transnational revolution and speculating on "its implications for politics at the national and international level").

7. Susan Strange, Big Business and the State, in MUltinationals In THE Global Political ECONOMY 101, 104-07 (Lorraine Eden \& Evan H. Potter eds., 1993).

8. Huntington, supra note 6 , at 344 (where "American mode" means the mode in the United States).

9. E.g., Yao-Su Hu, Global or Stateless Corporations are National Firms with International Operations, CAL. MGMT. REV., Winter 1992, at 107.

10. RoBert B. Reich, The WORK of Nations: PreParing OURSElves For 21ST CentuRY CaPitalism 3 (1991).

11. Kenichi Ohmae, An Excerpt from: The Borderless World, MCKINSEY Q., no. 3, June 1,1990 , at 3 . 
an era when these corporations' de facto independency from a certain nation-state as their home base is growing (see section III).

A further examination is also needed because the analysis of transnational corporations from a specifically legal perspective remains underdeveloped. Whereas numerous economic contributions treat the inner structure of transnational corporations, ${ }^{12}$ law scholars largely focus on the external relationships of the corporation and regulatory issues like supervision, taxation, or liability. ${ }^{13}$ It is remarkable that even the most important economic standard literature on transnational corporations is hardly taken into account in the legal discourse. Alan Rugman, author of the seminal book, Inside the Multinationals: The Economics of Internal Markets, notes that since its publication in 1981 the book has been cited 215 times in academic scholarship-but only three times in legal contributions. ${ }^{14}$

In legal discourse, the corporation was originally treated as an object regulated by nation-states; its inner functioning remained out of focus. More recent legal publications have differentiated the role of the corporation in more detail. Particularly, the literature on corporate social responsibility (CSR) has boomed over the last decades. ${ }^{15}$ This debate was accompanied by literature on the treatment of transnational corporations under international $\operatorname{law}^{16}$ and the role of corporations as

12. E.g., RichaRd E. CAVES, MUltinational ENTERPRISE AND ECONOMIC ANALYSIS (1982); JOHN H. DUNNING \& SARIANNA M. LUNDAN, MUlTINATIONAL ENTERPRISES AND THE Global ECONOMY (2d ed. 2008); ChARLES P. KINDLEBERgER, AMERICAN BusinesS ABROAD: SiX LECTURES ON DIRECT INVESTMENT 179-210 (1969); ALAN M. RUGMAN, INSIDE THE Multinationals: THE EConomics of INTERNAL MARKETS (1981); David J. Teece, Multinational Enterprise, Internal Governance, and Industrial Organization, 75 AM. ECON. R. 233 (1985).

13. E.g., Robert O. Keohane \& Van Doorn Ooms, The Multinational Firm and International Regulation, in TRANSNATIONAL CORPORATIONS AND WORLD ORDER: READINGS IN INTERNATIONAL POLITICAL ECONOMY 271-87 (George Modelski ed., 1979); Detlev F. Vagts, The Multinational Enterprise: A New Challenge for Transnational Law, 83 HARV. L. REV. 739, 739 (1970).

14. AlaN M. RUgman, InSIDE the Multinationals 25Th ANNIVERSARy Edition: The ECONOMICS OF INTERNAL MARKETS xxiv tbl.A1.1, tbl.A1.2 (2006).

15. E.g., Andreas Georg Scherer et al., Global Rules and Private Actors: Toward a New Role of the Transnational Corporation in Global Governance, 16 BUS. ETHICS Q. 505 (2006); David Weissbrodt \& Muria Kruger, Norms on the Responsibilities of Transnational Corporations and Other Business Enterprises with Regard to Human Rights, 97 AM. J. INT'L. L. 901 (2003).

16. Jonathan I. Charney, Transnational Corporations and Developing Public International Law, 1983 DUKE L.J. 748 (1983); Fleur Johns, The Invisibility of the Transnational Corporation: An Analysis of International Law and Legal Theory, 19 MELB. U. L. REV. 893 (1994). 
legislators of their own legal regimes. ${ }^{17}$ However, these branches of research treat only follow-up problems; further research is needed in order to better understand the inner functioning of the transnational corporation. The merits of specific legal discourses, like the CSR debate, could be expounded if legal scholars were better able to understand the corporation itself as the starting point of concerns about its responsibility. From this perspective, the recent debate over transnational corporate governance points in the right direction. ${ }^{18}$

In order to set the stage for the discussion in the following contributions, the remainder of this introduction briefly addresses three issues. First, what is a transnational corporation? Second, how important are transnational corporations for world trade? And third, how transnational are transnational corporations? This introduction then concludes with a brief overview of the contributions in this issue.

\section{The Concept of Transnational CoRPorations}

From a legal perspective, the concept of the transnational corporation is quite vague because it does not denote a single corporation, but rather an enterprise consisting of multiple corporations or other business entities integrated into a multinational firm. Such integration may take different forms. The classic form is a corporate group in which a parent company controls its subsidiaries by virtue of equity shares or other forms of ownership. ${ }^{19}$ This hierarchical type of the transnational corporation, however, no longer fully reflects modern practices of firm organization. Today, formally independent business units are also integrated into the global supply and distribution chains via long-term contractual arrangements. For instance, in the case of international subcontracting, licensing, or contract manufacturing,

17. Larry Catá Backer, Multinational Corporations as Objects and Sources of Transnational Regulation, 14 ILSA J. INT’L \& COMP. L. 499 (2008); Larry Catá Backer, Multinational Corporations, Transnational Law: The United Nations' Norms on the Responsibilities of Transnational Corporations as a Harbinger of Corporate Social Responsibility in International Law, 37 ColuM. HuM. RTS. L. REV. 287 (2006); Peter T. Muchlinski, 'Global Bukowina' Examined: Viewing the Multinational Enterprise as a Transnational Law-making Community, in GLOBAL LAW WITHOUT A STATE 79 (Gunther Teubner ed., 1997); Jean-Philippe Robé, Multinational Enterprises: The Constitution of a Pluralistic Legal Order, in GLOBAL LAW WITHOUT A STATE, supra, at 45.

18. See Gralf-Peter Calliess \& PeEr Zumbansen, Rough Consensus and RunNing CODE: A THEORY OF TRANSNATIONAL PRIVATE LAW 181-247 (2010).

19. This form has been denoted as the "Anglo-American 'Pyramid' Group." PETER T. MUCHLINSKI, MULTINATIONAL ENTERPRISES AND THE LAW 56 (2d ed. 2007). 
control is exercised on the basis of economic dependency. ${ }^{20}$ Particularly in modern knowledge-based industries, flexibility is a more vital factor than the control of assets. ${ }^{21}$ In terms of the classical dichotomy of market and firm established by transaction cost economics, the modern transnational corporation is situated as a hybrid between these two extremes, employing governance mechanisms from both sides. ${ }^{22}$

Therefore, new approaches to defining transnational corporations are often quite general. According to the Guidelines on Multinational Enterprises released by the Organization for Economic Co-operation and Development, multinational enterprises

usually comprise companies or other entities established in more than one country and so linked that they may co-ordinate their operations in various ways. While one or more of these entities may be able to exercise a significant influence over the activities of others, their degree of autonomy within the enterprise may vary widely from one multinational enterprise to another. ${ }^{23}$

The essential feature here is the ability of one or several corporate units to control the others, no matter whether their links are arranged by means of equity shares or by contract only.

20. Gary Gereffi et al., The Governance of Global Value Chains, 12 REv. INT'L PoL. ECON. 78, 81 (2005) ("The key insight is that coordination and control of global-scale production systems, despite their complexity, can be achieved without direct ownership.").

21. See DUNNING \& LUNDAN, supra note 12 , at 125-26.

22. See Gralf-Peter Calliess \& Jens Mertens, Transnational Corporations, Global Competition Policy, and the Shortcomings of International Private Law, 18 IND. J. GLOBAL LEGAL STUD. (2011); see also Walter W. Powell, Neither Market nor Hierarchy: Network Forms of Organization, 12 RES. IN ORGANIZATIONAL BEHAV. 295, 297 (1990); see generally Theresia Theurl, From Corporate to Cooperative Governance, in ECONOMICS OF INTERFIRM NETWORKS 149 (Theresia Theurl ed., 2005).

23. ORG. ECON. Co-OpERATION \& DEV., OECD Guidelines For Multinational ENTERPRISES: TEXT, COMMENTARY AND CLARIFICATIONS 12 (2008), available at http://www.oecd.org/document/28/0,3746,en_2649_34889_2397532_1_1_1_1,00.html (click "English" hyperlink in middle of page); see also DUNNING \& LUNDAN, supra note 12, at 3 ("A multinational or transnational enterprise is an enterprise that engages in foreign direct investment (FDI) and owns or, in some way, controls value-added activities in more than one country."). 